\title{
S20 - Percepción de salud y exposición a riesgos de trabajadores del sector comercio informal de Nicaragua y El Salvador
}

\author{
Meyling Gutiérrez-López \\ Maestría en Salud Ocupacional, Universidad Nacional Autónoma de Nicaragua, León, Nicaragua. \\ *Autor al que se dirige la correspondencia: auroraragon@gmail.com
}

\section{Resumen}

— 1 objetivo fue determinar la relación entre la percepción de salud y la exposición a riesgos ocupacionales de - trabajadores del sector comercio de Nicaragua y El Salvador considerando los determinantes sociales. Se trabajó con un diseño de triangulación concurrente, combinando métodos cualitativos y cuantitativos. En El Salvador la percepción de salud es buena (70\%) y en Nicaragua media (49\%). A nivel cualitativo en ambos países la salud es vista desde un concepto económico, estrés y ausencia de enfermedades. En Nicaragua las percepciones más altas de riesgos son atender varias tareas simultaneamente (59\%), nivel de atención alto (57.5\%), movimientos repetitivos (50\%). En El Salvador, el nivel de atención alto (63\%), el trabajo de pie (60\%), atender varias tareas simultaneamente y esconder emociones en el trabajo (41\%) con movimientos repetitivos (40\%). Cualitativamente se perciben riesgos de inseguridad ciudadana, accidentes y conflictos. En Nicaragua la edad, la pobreza y el no acceso al seguro social $(\mathrm{P}<.05)$ están asociados a mala salud, estar casado es un factor protector. En El Salvador sólo la edad y la iluminación están asociadas a mala salud, trabajar con plazos estrictos y cortos es un factor protector de salud. No se encontró relación entre la percepción de salud y la exposición a riesgos ocupacionales, por que los riesgos se perciben de manera diferente. Mientras en El Salvador hay una relación entre iluminación deficiente y mala salud; en Nicaragua, son determinantes sociales como pobreza y el no acceso a la seguridad social los que están fuertemente asociados a percibir una mala salud.

Palabras claves: Riesgos ocupacionales, inseguridad ciudadana

\section{Abstract}

$\mathrm{D}$ etermine the relationship between perceived health and exposure to occupational hazards in trade workers sector in Nicaragua and El Salvador, taking into account the social determinants of health. Design was a concurrent triangulation, combining qualitative and quantitative methods. In El Salvador, perceived health is mostly good $(70 \%)$ and Nicaragua it is fair $(49 \%)$. A qualitative level in both countries, health is seen from an economic concept, stress and absence of disease. In Nicaragua, the highest risk perceptions are addressing several tasks simultaneously (59\%), high level of attention (57.5\%), repetitive movements (50\%). In El Salvador, high level of attention (63\%), standing at work $(60 \%)$, attending several tasks simultaneously and hide emotions at work (41\%) and repetitive movements (40\%). Qualitatively risks of insecurity, accidents and conflicts are perceived. In Nicaragua age, poverty and lack of access to social security $(\mathrm{P}<.05)$ are associated with poor health and being married is a protective factor. In El Salvador, only age and lighting are associated with poor health and work within strict and short deadlines is a protective factor of health. No relationship between perceived health and exposure to occupational hazards was found, which is because the risks are perceived differently (public safety risks). While in El Salvador there is a link between poor lighting and poor health; in Nicaragua, are social determinants such as poverty and lack of access to social security, which are strongly associated with perceived poor health.

Keywords: occupational hazards, citizen insecurity 